\title{
Strategy Analysis of Ponggok Rural Tourism Development into Integrated Tourism Area
}

\author{
Zahrotun Satriawati $^{1}$, Rahmat Ingkadijaya $^{2}$, Sri Sulartiningrum ${ }^{3}$ \\ ${ }^{1}$ Sekolah Tinggi Pariwisata Ambarrukmo Yogyakarta \\ 2,3 Sekolah Tinggi Pariwisata Trisakti \\ 12abro_satria@yahoo.com
}

\begin{abstract}
The development of tourism can help the welfare of the rural population through developing a tourist village concept. The potential of the village can be used as a tourist attraction. Klaten Regency has a very abundant potential of springs that located in Ponggok village which is mostly used by local residents for irrigating rice fields, agriculture, and fish cultivation. However, the existing springs in the Ponggok village are now used as tourist destinations that spread across several locations, such as Umbul Ponggok, Umbul Sigedang, Umbul Besuki, Waduk Galau/Banyu Mili. This study uses qualitative and quantitative descriptive analysis and the data obtained through questionnaires distributed and completed by respondents as many as 135 respondents. SWOT analysis is employed to investigate internal and external factors to analyze Ponggok Tourism Village development strategy towards integrated tourism area.
\end{abstract}

Keywords: Rural Tourism, development, integrated tourism area 


\section{A. Introduction}

Tourism has an important role in national development for its contribution of foreign exchange. Tourism development and other sectors must be supported each other. In addition, the natural resources are very potential to be developed as a tourist destination.

Klaten Regency has many tourist destinations which ares completed with various facilities and infrastructure. The tourist destinations in this area covers various sectors, one of them is rural tourism. Ponggok Tourism Village is an area that worth visiting because there are several destinations in the form of natural spring, such as Umbul Ponggok, Umbul Besuki, Umbul Sigedang, and Waduk Galau / Banyu Mili which are located in an area of Ponggok village. In addition to being used as a tourist destination, those springs are used for irrigation, fish farming, and agriculture. Umbul Ponggok is the most favorite tourist destination in Ponggok Tourism Village since it offers newer tourist attraction in the form of snorkeling and underwater photo session which is now a new tourist trend in the area.

According to Medium Term Development Plan, Ponggok Tourism Village will be developed into an integrated tourism area so that interdestinations become mutually integrated. According to Yoeti (1996), tourism Village is a rural area that has some special characteristics to become a tourist destination. In rural areas, the population generally still has traditions and cultures that are relatively original and maintained. In addition, several supporting factors such as typical food, agricultural systems, and social systems also support a tourist village area. Beyond these factors, nature and environment are still original and is one of the most important factors of a tourist destination. In its development, some aspects needs to be analyzed to emphasizes the tourist attractions, accessibility for the mobility of tourists, amenities, and supporting facilities.

Table 1. The Number of Visitors in Umbul Ponggok 2010-2016

\begin{tabular}{ccc}
\hline No & Year & Visitors \\
\hline 1 & 2010 & 5.362 \\
2 & 2011 & 33.604 \\
3 & 2012 & 41.865 \\
4 & 2013 & 65.000 \\
5 & 2014 & 167.445 \\
6 & 2015 & 367.000 \\
7 & 2016 & 495.621 \\
\hline
\end{tabular}

Based on the table it can be seen that tourist visits in one of Umbul Ponggok has increased every year. It shows that other destinations will also be affected by tourist visits. At present, tourist visits still focus on Umbul Ponggok, despite the availability of similar tourist destinations nearby. It might due to inadequate facilities to the destinations. 


\section{B. Literature Review}

\section{Umbul Ponggok Village as a Tourist Destination}

According to Leiper (1990), the destination is a place where the complexity of the tourism activity occurs. Tourism destination is an entity in a certain geographical area within which there are components of tourism and service products,as well as other supporting elements such as tourism industry actors, communities, and developer institutions that form a synergistic system in creating the motivation of visits and the totality of visits for the tourists (Pitana and Diarta, 2009).

Cooper et al. (1993) mentions 4 aspects to successfully develop a tourist destination:

1. Attraction, Attraction is a significant component in attracting tourists. An area can be a tourism destination if conditions support to be developedinto a tourist attraction. The existence oftourist attraction is the reason and the motivationof tourists to visit a tourismdestination.

2. Accessibility, Accessibility is the most important thing in tourism activities. All kinds of transportationor transportation services becomeanimportantaccess in tourism.If an area has tourismpotential,it must provide adequateaccessibilitysothatthe area canbevisited.

3. Amenities, Amenity is all kinds of facilities and infrastructureneeded bytourists during their stayin a tourist destination including hotels, restaurants, transportations and travel agencies.

4. Ancillary service, Ancillary related to things that support tourism,suchasmanagementagencies, touristinformation, travel agent and stakeholders whoplay a role in tourism.

Green (2001) mentions that amenities can be value in the experience of tourists who travel. So, amenities are service that must exist in a tourist destination. Facilities in Ponggok tourism village is not spread evenly. It mostly located around Umbul Ponggok. Ponggok tourism village development activities are performed by maximizing the potential of natural resources, providing tourism facilities and infrastructure, developing soft skill quality for the managers, widening the involvement of local governments and central government, inviting private companies to support the development, as well as involving local community.

Sharpley (2002) argues that tourism village development is expected to be able to make a major contribution to the development of village areas and the community itself because long-term financial and technical support policy elements are very important if tourism can play an effective role of rural development. According to Ashartono, Rahmanita, and Lemy (2018), the management of a tourist destination cannot be separated from the participation of the community, especially the community around the tourist destination area. This development will also later empower the community to participate in its management. 


\section{Methods}

The kind of this research is qualitative and quantitative descriptive research. Data sources are obtained through primary and secondary data. Data obtained through questionnaires distributed and filled by respondents as many as 135 respondents, besides that the data was obtained through direct observation and interviews with visitors and managers.

In this study the analytical method used to analyze is descriptive analysis to determine internal factors in the form of strengths and weaknesses and external factors in the form of opportunities and threats faced in developing Ponggok Rural tourism. Meanwhile, to answer the strategy of developing Ponggok Rural tourism into an integrated tourism area using SWOT analysis. Analysis of internal and external factors are strategic factors in the internal and external environment by giving weighting and rating on each strategic factor of the strengths, weaknesses, opportunities, and threats that affect the existing conditions and situations and provide benefits when it is done properly. Analyze the internal environment (IFAS) to find out the possibilities of strengths and weaknesses. while analyzing the external environment (EFAS) to find out various possible opportunities and threats.

\section{Result/ Discussion}

Potential of Ponggok tourism is in the form of rural tourism that presents panoramic sources of springs that are still natural and which is also used by local people for daily needs and can be utilized as a tourism sector because it has an attraction for tourists. The attractiveness of an un-ordinary source of springs can be found in various other areas which can be a source of income for the local population for the improvement of welfare and economy. The tourist destinations that can be visited in Ponggok Tourism Village are:

Table 2. Tourism Destinations in Ponggok Tourism Village

\begin{tabular}{|c|c|c|c|}
\hline No & Tourist Destination & Potential & Location \\
\hline 1 & Umbul Ponggok & $\begin{array}{ll}\text { - } & \text { Swimming Pool } \\
\text { - } & \text { Snorkeling, Swimming } \\
\text { - } & \text { Photo Underwater } \\
\text { - } & \text { Water Sports } \\
\text { - } & \text { Wedding Reception Venue } \\
\text { - } & \text { Café and Live Music }\end{array}$ & Ponggok \\
\hline 2 & Umbul Sigedang & $\begin{array}{l}\text { - } \quad \text { Swimming } \\
\text { - } \quad \text { Orchards and Mini Zoo }\end{array}$ & $\begin{array}{l}\text { Dusun } \\
\text { Umbulsari }\end{array}$ \\
\hline 3 & Umbul Besuki & $\begin{array}{ll}\text { - } & \text { Outbound } \\
\text { - } & \text { Fishing } \\
\text { - } & \text { Rafting } \\
\text { - } & \text { Jogging Track } \\
\text { - } & \text { Disaster Mitigation }\end{array}$ & $\begin{array}{l}\text { Dusun } \\
\text { Kiringan }\end{array}$ \\
\hline
\end{tabular}




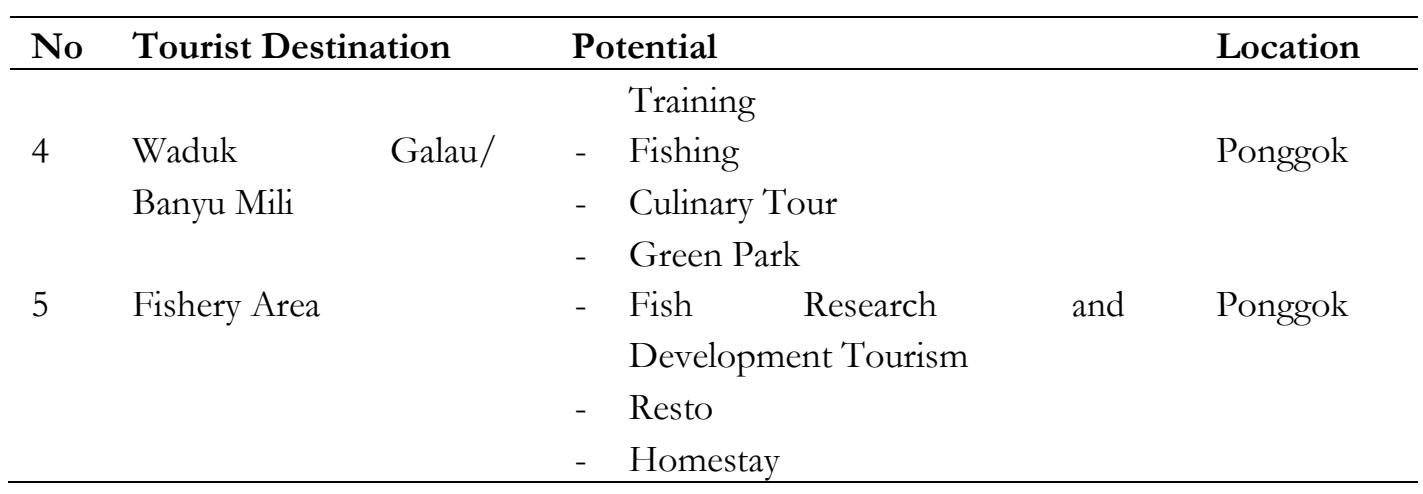

To increase tourist visits, a comprehensive development in these destinations is needed to harmonize the concept of integrated tourism that needs significant and integrated development.

In developing the Ponggok Village Strategy into an integrated tourism area, SWOT Matrix Analysis was used to obtain internal factors such as Strengths, Weaknesses, and external factors such as Weaknesses (opportunities), and Threats.

After analyzing internal conditions in the form of strengths, weaknesses and external conditions in the form of opportunities and threats, then the calculation of internal and external factor weights is carried out to determine the location of the strategic development quadrant. The calculation of the factor weight is done by making a tabulation score IFAS - EFAS (Internal - External Strategic Factor Analysis Summary). The following is the calculation of the internal and external factor weights contained in the IFAS and EFAS analysis tables shown in the table below.

Table 3. Internal Factor Analysis (IFAS)

\begin{tabular}{|c|c|c|c|c|}
\hline $\begin{array}{c}\mathrm{N} \\
\mathrm{O}\end{array}$ & Internal Factor & $\begin{array}{c}\text { VALUE } \\
\% \\
\end{array}$ & RATING & $\begin{array}{c}\text { SCORE }= \\
\text { Value X } \\
\text { Rating }\end{array}$ \\
\hline \multicolumn{5}{|c|}{ Strengths $(\mathrm{S})$} \\
\hline 1 & $\begin{array}{l}\text { Ponggok Tourism Village is very } \\
\text { interesting to visit because of its } \\
\text { natural attractions and beautiful } \\
\text { scenery }\end{array}$ & 0,08 & 3 & 0,28 \\
\hline 2 & $\begin{array}{l}\text { Spring is the main attraction in } \\
\text { Ponggok Tourism Village }\end{array}$ & 0,11 & 4 & 0,49 \\
\hline 3 & $\begin{array}{l}\text { Snorkeling activities become a } \\
\text { mainstay tourist attraction that } \\
\text { attracts tourists }\end{array}$ & 0,09 & 4 & 0,35 \\
\hline 4 & $\begin{array}{l}\text { Clear water qualities and } \\
\text { snorkeling tourism activities }\end{array}$ & 0,07 & 3 & 0,21 \\
\hline 5 & Good security conditions & 0,10 & 4 & 0,42 \\
\hline 6 & $\begin{array}{l}\text { Access to tourist sites is easy to } \\
\text { reach }\end{array}$ & 0,06 & 2 & 0,13 \\
\hline
\end{tabular}


Strategy Analysis of Ponggok Rural Tourism Development into Integrated Tourism

\begin{tabular}{clccc}
\hline $\mathrm{N}$ & \multicolumn{1}{c}{ Internal Factor } & $\begin{array}{c}\text { VALUE } \\
\mathrm{O}\end{array}$ & $\begin{array}{c}\text { SCORE }= \\
\text { Value X } \\
\text { Rating }\end{array}$ \\
\hline 7 & $\begin{array}{l}\text { A lot of signposts are available } \\
\text { for tourist sites }\end{array}$ & 0,07 & 3 & 0,20 \\
\hline & STRENGTH & & 2,07 \\
\hline Weakness (W) & 0,05 & 2 & 0,11 \\
\hline 1 & Narrow land & 0,07 & 3 & 0,17 \\
\hline 2 & Parking facilities are inadequate & & 0,11 \\
\hline & $\begin{array}{l}\text { Lodging / homestay facilities in } \\
\text { Ponggok Tourism Village } \\
\text { is not maximized yet }\end{array}$ & 0,05 & 2 & 0,12 \\
\hline 4 & $\begin{array}{l}\text { Public transportation to tourist } \\
\text { destinations is rarely obtained }\end{array}$ & 0,05 & 2 & 0,17 \\
\hline 5 & $\begin{array}{l}\text { Road accessibility is still not } \\
\text { good }\end{array}$ & 0,07 & 3 & 0,12 \\
\hline 6 & $\begin{array}{l}\text { Lack of professional workforce in } \\
\text { managing tourism objects }\end{array}$ & 0,06 & 2 & 0,14 \\
\hline 7 & $\begin{array}{l}\text { Don't have a tourist information center } \\
\text { AMOUNT OF WEAKNESS }\end{array}$ & 0,06 & 2 \\
\hline & \begin{tabular}{l} 
TOTAL NUMBER OF IFAS \\
\hline
\end{tabular} & 1,00 & & 3,01 \\
\hline
\end{tabular}

Table 4. External Factor Analysis (EFAS)

External Factor Analysis (EFAS)

\begin{tabular}{|c|c|c|c|c|}
\hline $\begin{array}{l}\mathbf{N} \\
\mathbf{o}\end{array}$ & External Factors & $\begin{array}{c}\text { BOBOT } \\
\%\end{array}$ & RATING & $\begin{array}{c}\text { SCORE= } \\
\text { Bobot X } \\
\text { Rating } \\
\end{array}$ \\
\hline \multicolumn{5}{|c|}{ Opportunities $(\mathrm{O})$} \\
\hline 1 & $\begin{array}{l}\text { Increasing tourism products and } \\
\text { attractions by exploiting potential }\end{array}$ & 0,12 & 4 & 0,44 \\
\hline 2 & $\begin{array}{l}\text { The interest of tourists visiting } \\
\text { natural attractions is still high }\end{array}$ & 0,09 & 3 & 0,25 \\
\hline 3 & Support of tourism businesses & 0,07 & 2 & 0,15 \\
\hline 4 & Improving the economy of local residents & 0,12 & 3 & 0,37 \\
\hline 5 & $\begin{array}{l}\text { Support government policy for } \\
\text { the development of the tourism } \\
\text { sector }\end{array}$ & 0,11 & 3 & 0,34 \\
\hline 6 & Increased private investment & 0,07 & 2 & 0,15 \\
\hline 7 & $\begin{array}{l}\text { Strong technology and } \\
\text { information development }\end{array}$ & 0,08 & 2 & 0,18 \\
\hline & AMOUNT OPPORTUNITIES & & & 1,88 \\
\hline
\end{tabular}


Strategy Analysis of Ponggok Rural Tourism Development into Integrated Tourism

\begin{tabular}{lllcc}
\hline $\begin{array}{c}\mathbf{N} \\
\mathbf{0}\end{array}$ & External Factors & $\begin{array}{c}\text { BOBOT } \\
\%\end{array}$ & RATING & $\begin{array}{c}\text { SCORE }= \\
\text { Bobot } \mathbf{X} \\
\text { Rating }\end{array}$ \\
\hline Treath (T) & 0,08 & 2 & 0,18 \\
\hline $1 \quad \begin{array}{l}\text { Developing similar tourism } \\
\text { objects can increase competition }\end{array}$ & 0,08 & 2 & 0,16 \\
\hline 2 & $\begin{array}{l}\text { The occurrence of natural } \\
\text { disasters }\end{array}$ & 0,10 & 3 & 0,31 \\
\hline 3 & $\begin{array}{l}\text { Environmental pollution due to } \\
\text { exploitation of tourist visits }\end{array}$ & 0,07 & 2 & 0,14 \\
\hline 4 & $\begin{array}{l}\text { Cultural influences brought by } \\
\text { tourists }\end{array}$ & & 0,80 \\
\hline & AMOUNT THREATS & 1,00 & 2,67 \\
\hline & TOTAL NUMBER OF EFAS
\end{tabular}

Table 5. Result

\begin{tabular}{c|c|c}
\hline No & Description & Score \\
\hline 1 & Internal Factor & \\
& - Strength & 2,07 \\
& - Weakness & 0,94 \\
\hline 2 & External Factor & \\
& - Opportunities & 1,88 \\
& - Threats & 0,80 \\
\hline
\end{tabular}

Based on the quadrant layout formulation in the figure above, the strategy to be implemented in the framework of developing the Ponggok Tourism Village towards a suitable village is in quadrant I or internal and internal structure (growth strategy) which is a strategy designed to reach the number of tourist visits (source of information) establish cooperation between stakeholders, support activities, improve quality which is the right factor.

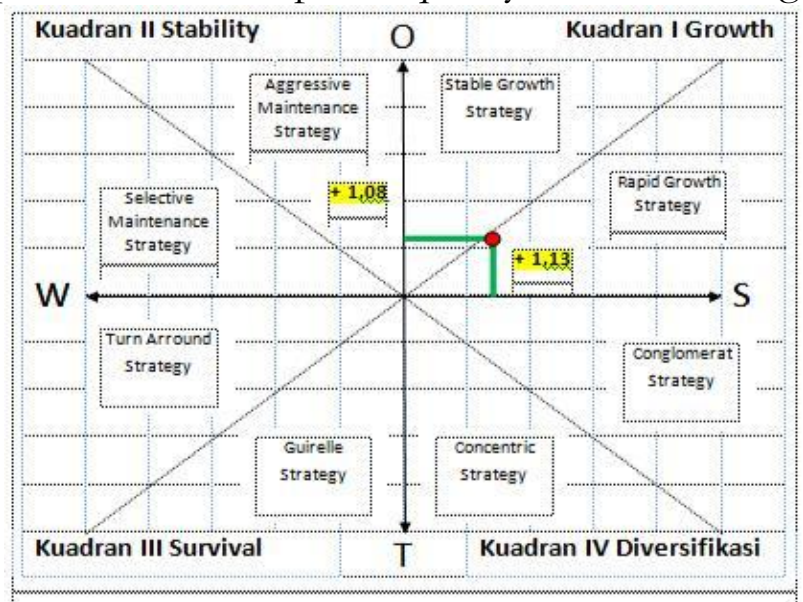

Figure 1. Quadrant

Tourism Research Journal, Volume 3 (1), 2019 
Based on the above quadrant, the strategy in quadrant $I$ is included in the Rapid growth strategy to increase the growth rate of number tourist visits with a faster time (second year is greater than the first and next year), quality improvement is a strength factor for maximize the utilization of all opportunities.

By utilizing strategic factors in the form of strengths such as nature tourism and beautiful scenery, it is very interesting to visit, a spring that can be used as a main attraction, snorkeling activities become a mainstay attraction, clear water quality meets the requirements of the activity, security conditions well, access to tourist sites is easy to reach, and there are many signposts available to the location, as well as opportunities to improve tourism products and attractions by utilizing the available potential, tourists' interest in natural tourism that is still high, support from tourism businesses, improving the economy of the local people, getting government policy support for the development of the tourism sector, increasing private investment, developing technology and strong information can make the development of the tourism sector stronger.

Strategies that can be carried out for the development of integrated tourism areas in Ponggok Tourism Village are presented in the form of a SWOT Matrix. SWOT matrix is a matrix that interacts with internal and external strategic factors. This matrix can describe clearly how the opportunities and threats (external) faced can be adjusted to the strengths and weaknesses (internal) that they have. SWOT analysis matrix for the development of integrated tourism areas Ponggok Tourism Village

Table 6. Matrix SWOT Analysis

\begin{tabular}{|c|c|}
\hline Internal Factors & External Factors \\
\hline 1. Strength & 3. Opportunities \\
\hline $\begin{array}{l}\text { a. Ponggok Tourism Village is very } \\
\text { interesting to visit because of its natural } \\
\text { attractions and beautiful scenery } \\
\text { b. Spring is the main attraction in Ponggok } \\
\text { Tourism Village } \\
\text { c. Snorkeling activities become a mainstay } \\
\text { tourist attraction that attracts tourists } \\
\text { d. Clear water qualities and snorkeling } \\
\text { tourism activities } \\
\text { e. Good security conditions } \\
\text { f. Access to tourist sites is easy to reach } \\
\text { g. A lot of signposts are available for } \\
\text { tourist sites }\end{array}$ & $\begin{array}{l}\text { a. Increasing tourism products and } \\
\text { attractions by exploiting potential } \\
\text { b. The interest of tourists visiting } \\
\text { natural attractions is still high } \\
\text { c. Support of tourism businesses } \\
\text { d. Improving the economy of local } \\
\text { residents } \\
\text { e. Support government policy for the } \\
\text { development of the tourism sector } \\
\text { f. Increased private investment } \\
\text { g. Strong technology and information } \\
\text { development }\end{array}$ \\
\hline
\end{tabular}




\begin{tabular}{|c|c|}
\hline Internal Factors & External Factors \\
\hline 2. Weakness & 4. Threats \\
\hline $\begin{array}{l}\text { a. Narrow land } \\
\text { b. Parking facilities are inadequate } \\
\text { c. Lodging / homestay facilities in } \\
\text { Ponggok Tourism Village are not yet } \\
\text { maximal } \\
\text { d. Public transportation to tourist } \\
\text { destinations is rarely obtained } \\
\text { e. Road accessibility is still not good } \\
\text { f. Lack of professional workforce in } \\
\text { managing tourism objects } \\
\text { g. Don't have a tourist information center }\end{array}$ & $\begin{array}{l}\text { a. Developing similar tourism objects } \\
\text { can increase competition } \\
\text { b. The occurrence of natural disasters } \\
\text { c. Environmental pollution due to } \\
\text { exploitation of tourist visits } \\
\text { d. Cultural influences brought by } \\
\text { tourists }\end{array}$ \\
\hline
\end{tabular}

From the results of IFAS and EFAS analysis produced in the quadrant layout graph, the right strategy to use is the SO strategy because it is considered to have the highest priority and urgency to be implemented. The strategy that can be applied to make Ponggok Tourism Village an integrated tourism are as the following:

1. Maintaining and developing special interest tourism attractions (snorkeling, nature tours). Snorkeling in fresh water is a favorite tourist attraction in the Ponggok tourist village, especially in the tourist destinations of Pabulegong. Many tourists are interested in visiting Ponggok Bannerman than other tourist destinations in Ponggok Village. The growing popularity of snorkeling leads to working opportunities such as provision of complete Snorkeling equipment, to be tour guides and also snorkeling instructors. The destination should be completed with supporting facilities, as well as adequate facilities and infrastructure to ensure integration in making travel packages or integrated tour packages.

2. Maintaining the environment of Ponggok village so that the springs are not polluted. Increasing awareness and distribution of information to the villagers to be able to collaborate together to maintain the sustainability and authenticity of the village's natural environment and sources of springs that are the mainstay of local residents because they can be used as fields for fisheries, irrigation and tourism sectors.

3. Making collaboration with tourism stakeholders and travel agents to create integrated tour packages. In developing integrated tourism areas there needs to be continuity between one destination to another tourist destination that is still in a tourist area. To be able to reach all tourist areas there needs to be an integrated tour package made by a travel agency and also need special transportation to take tourists to various tourist destinations in the Ponggok village area because this can make it easier for tourists to tour the Ponggok Village tourism area. 
4. Providing easy access to the Tourism Village. Ease of access to tourist areas is the main thing that is a decision of tourists in visiting a tourist destination. In addition, tourists hope to easily reach information at one time. Information centers will provide access to tourist areas so that tourists do not need to search and ask questions about the community. This center provides all the information needed by tourists while in the tourist area of Ponggok Village. So it is necessary to develop a Tourist Information Center (TIC) because in every tourist area it is very necessary to have the existence of TIC because it can become an information center by utilizing the local community in order to provide clear information related to Ponggok Tourism Village.

5. Creating security so that visitors are comfortable at tourist sites. The factor of comfort and safety in a tourist area is an added value and opportunity to be visited by tourists to provide an alternative tour with a guarantee of safety and security for tourists during a tour. To create it, there needs to be cooperation with related parties and local communities to make regulations in accordance with village customs.

6. Utilizing information technology advancements for promotional activities. Promotional activities can be carried out by holding tourism promotions with travel agents who can provide benefits in minimizing the budget spent on promotional activities of the manager in selling tourism products in the integrated tourism area of Ponggok Village and can make it easier for tourists to obtain tourist information.

\section{E. Conclusion}

Based on the results of the analysis and discussion described earlier, the conclusion of the development of Ponggok tourism village to integrated tourism area are :

1. The strength factor that can support the development of Ponggok Tourism Village is the diversity of tourist attractions in several Ponggok tourism destinations, namely Umbul Ponggok, Umbul Sigedang, Umbul Besuki, Galau \& Banyu Mili Reservoir, Fisheries Area by utilizing springs for the tourism and fisheries sectors. Snorkeling tourist attractions in freshwater become a tourist attraction mainstay of good security conditions, and ease of access to reach locations, this must be maintained because considering the ease of achieving a tourist destination is the main choice of tourists to visit tourism destination.

2. The inhibiting factors are the finding of weaknesses in the form of narrow land constraints for development, inadequate parking facilities because it still uses local people's land, the absence of a tourist information center, the lack of professionals in managing tourism objects, public transportation to the Ponggok Tourism Village still rarely found. 
3. Factors Opportunities that support the development of the Ponggok Tourism Village are the support of tourism businesses and the support of government policies on the development of the tourism sector. As well as inhibiting development is a narrow land condition resulting in a development that cannot be maximized such as a parking lot that still uses land owned by residents.

4. Priority strategy for tourism development in Ponggok Tourism Village is to maintain and complete snorkeling facilities, build networks with other tourist destinations, collaborate with travel agents to create integrated tour packages in Ponggok Tourism Village. Ponggok village area has many tourist destinations that are worth visiting and making it an integrated village area there must be continuity between one destination and another, making a tour guide community. Tour guides are tourism ambassadors of the origin of the destination because as a tour guide is expected to be a partner/source of information for tourists, technological developments can be used to facilitate tourist information to tourists, managing homestays by utilizing people's homes to be used as tourist places.

5. Threats that are experienced in developing similar tourism objects can increase competition for similar products, it is necessary to carry out several innovations and revitalization in some facilities supporting tourism activities, the occurrence of natural disasters, environmental pollution due to exploitation of tourist visits, and cultural influences brought by tourists.

\section{F. Recommendation}

1. The community is a top priority in the management of the Ponggok Tourism Village, it is hoped that the community are able to manage well with the knowledge and expertise (soft skills)

2. The development of rural tourism is expected to be sustainable which is not only a discourse but truly realized, because a village can develop in the tourism sector, the survival of the community can be well controlled.

3. It is hoped that the government will be more enthusiastic to participate and be able to determine policies that are constructive and empowering the community by working together to develop and develop the Ponggok village as a whole by equipping the community with the skills to manage tourism potential because it will become a village asset and new livelihood for the people of Ponggok Village.

4. In realizing an increase in the tourism sector in the Ponggok Tourism Village towards the Integrated Tourism Zone, it is expected that the management, the community, the Government, private investors, and stakeholders to collaborate in building the Ponggok Tourism Village into a leading integrated tourism destination. 


\section{REFERENCES}

Ashartono, Rakhmat., Myrza Rahmanita., and Diena Mutiara Lemy. 2018. The Effect of Destination Management and Community Participation to The Visitors Consumption at Tebing Breksi Sleman Yogyakarta. Tourism Research Journal. Vol. 2, No. 1: 1 - 13.

Cooper, Chris and John Fletcher e.t.c., 1993, Tourism Priciples \& Practise.

Green, G. P. (2001). Amenities and community economic development: Strategies for sustainability. Journal of Regional Analysis and Policy, 31(2), 61-76.

Leiper, N., 1990. Tourist attraction systems. Annals of Tourism Research, 17(2): 367-384.

Pitana, I Gede and Diarta, I Ketut Surya. 2009. Pengantar Ilmu Pariwisata. Yogyakarta: Penerbit Andi.

Renstra. Rencana Strategis Pengembangan Destinasi dan Industri Pariwisata. Kementerian Pariwisata Tahun 2015 -2019.

Sharpley, R. (2002). Rural tourism and the challenge of tourism diversification: the case of Cyprus. Tourism management, 23(3), 233-244.

Undang-Undang No. 10 Tahun 2009. Kepariwisataan. Jakarta: Departemen Pariwisata Budaya Republik Indonesia.

Undang-undang No. 26 Tahun 2007 tentang Penataan Ruang.

Yoeti, Oka A. 1996. Pemberdayaan dan Atraksi Pariwisata. Bandung: PT. Pradnya Paramita. 